ROCZNIKI HUMANISTYCZNE

Tom LXVIII, zeszyt $10 \quad-\quad 2020$

DOI: http://dx.doi.org/10.18290/rh206810-11

JOANNA MIREK

\title{
THE INTERPRETING PORTFOLIO \\ AS A SELF-REGULATION TOOL IN INTERPRETER TRAINING: PRELIMINARY FINDINGS FROM A PILOT STUDY
}

\section{INTRODUCTION}

One of the greatest challenges of today's education is to transform students into increasingly autonomous learners, thus, to prepare them for 'life-long learning'. It has been gradually recognized that translation and interpreting (T\&I) training aimed at empowering graduates to adapt to the highly dynamic job market needs to be promoted. Seeing the importance of having students take responsibility for their learning process, social constructivism seems particularly pertinent in this context (Pietrzak 820). As Kiraly (1) puts it, "in recent years, it has become a commonplace in educational psychology that knowledge is constructed by learners, rather than being simply transmitted to them by their teachers." Therefore, "the teacher does not instruct or transmit (...) ready-made educational solutions, but he or she creates an environment in which the instructor and the instructed become learners" (Klimkowski, "Assessment" 30). Hence, it is crucial to empower novice interpreters to become autonomous learners, who can both monitor and control their learning processes both in and outside the academia. In view of the above, T\&I trainers are expected to provide them with "individually tailored tools that will allow every student to function within the language mediation community upon graduation" (Kiraly 49). The main objective of this article is to advocate for two theses:

JoAnNA MiReK, MA, Research Associate - John Paul II Catholic University of Lublin, Institute of Linguistics, Department of the History of English and Translation Studies; address for correspondence: Al. Racławickie 14, 20-950 Lublin; e-mail: joanna.mirek@kul.pl. ORCID: https://orcid.org/ 0000-0001-6929-8608.

Mgr JoAnNA MiReK, asystent - Katolicki Uniwersytet Lubelski Jana Pawła II, Instytut Językoznawstwa; Katedra Historii Języka Angielskiego i Translatoryki; adres do korespondencji: Al. Racławickie 14, 20-950 Lublin; e-mail: joanna.mirek@kul.pl. ORCID: https://orcid.org/00000001-6929-8608. 
1) Novice interpreters need to be prepared for the professional life upon graduation, which can be achieved through introducing self-regulation tools into the interpreting classroom.

2) The SI Portfolio put forward in this article is an effective instrument implementing self-regulation, which entails novice interpreters (on a reiterative basis):

a) reflecting upon their own performance;

b) planning further learning activities based on prior self-reflection;

c) monitoring their progress.

This paper is an attempt to discuss the need for implementing tools fostering self-regulation in the interpreting classroom, such as the Simultaneous Interpreting (SI) Portfolio.

\section{SELF-REGULATION IN THE INTERPRETING CLASSROOM}

Reflective learning is essential in a profession like translation and interpreting, as gaining insights allows for efficient work and prospective improvement. Meeting the job market demands requires novice interpreters to possess "the ability to reflect upon, understand and control one's learning" (Schraw and Dennison). However essential, self-reflection is not enough to guarantee students' growth, as "the reflexive stage can only enhance learning when followed by a performative stage," which "takes place when learners employ their resources to transform self-reflection into planned actions, and (...) to complete the tasks that result from self-reflection" (Klimkowski, "Assessment" 28). The link between reflectivity and reaction that follows is defined by Moser-Mercer (14 f.) as self-regulation in the learning process in the following way:

(...) the type of behavioural feedback essential to skill acquisition, refers to the use of processes that activate and sustain thoughts, behaviours and affects in order to attain goals (...). It refers to the learners' ability to make adjustments in their own learning processes in response to their perception of feedback regarding their current status of learning. Self-regulation has three components: (1) self-observation - deliberate attention to specific aspects of one's own performance; (2) self-judgement - comparing one's current progress towards a goal with a standard (...); (3) self-reaction - making evaluative responses to judgements of one's own performance.

Self-regulated learners are expected to perform (reiteratively) the following five stages in the learning process: 
(1) they begin by analysing the task and interpreting task requirements in terms of their current knowledge and beliefs (...); (2) they set task-specific goals, which they use as a basis for selecting, adapting, and possibly inventing strategies that will help them accomplish their objectives (...); (3) (...) they monitor their progress towards goals, thereby generating internal feedback about the success of their efforts; (4) they adjust their strategies and efforts based on their perception of on-going progress (...); and (5) they use motivational strategies to keep themselves on task when they become discouraged or encounter difficulties. (Moser-Mercer 15)

Pietrzak ( $822 \mathrm{ff}$.) remarks that self-regulated learners are able to set clear goals, select appropriate strategies as well as to organise and monitor their work by managing time, reflecting upon the learning process, and applying feedback to improve their performance.

\subsection{REDEFINING THE INTERPRETING CLASSROOM}

Moser-Mercer's model of self-regulation is "a good example of how to integrate the role of the teacher (feedback, facilitating self-regulation etc.) with that of the learner (self-observation, self-judgement, internal feedback, etc.) in classroom assessment practices" (Klimkowski, "Assessment" 29). This model corresponds to the social constructivist approach in which both teachers and students become learners. Students become primary evaluators as they practise self-assessment, and the teacher is no longer the only person eligible to assess the students' performance. This approach also implies opening the interpreting classroom to polyphony of voices (cf. González Davies ): the monopoly of the teacher's narrative is replaced by the voice of the student in question and their peers. Empowering students forms them into autonomous interpreters, responsible for their own learning process, whereas teachers are given the unique opportunity to identify and respond to individual needs of the given student. Furthermore, Klimkowski ("Assessment" 30) remarks that teachers "can facilitate learners' transition from dependent to autonomous learning, including a shift from teacher-dependent assessment towards an autonomous self-assessment." This corresponds to Grow's model of the learner autonomy presented below. 
Table 1. Four stages of learner autonomy (Grow 129, in Klimkowski, Towards 154 f.).

\begin{tabular}{|c|c|c|c|}
\hline Stage & Student & Teacher & Education \\
\hline $\mathbf{1}$ & dependent & authority, coach & \multirow{2}{*}{ Institutional setting } \\
\cline { 1 - 2 } $\mathbf{2}$ & interested & motivator, guide & \\
\hline $\mathbf{3}$ & involved & facilitator & \multirow{2}{*}{ After graduation } \\
\hline $\mathbf{4}$ & self-directed & consultant, delegator & \multirow{2}{*}{. } \\
\hline
\end{tabular}

As Grow (127 ff.) remarks, "the goal of the educational process is to produce self-directed, life-long learners," and that "the ultimate task of a Stage 4 teacher is to become unnecessary," which reflects the situation when graduates have to learn without the teacher. Taken into account that professional interpreters are expected to work in a highly autonomous mode, students should be individually supported in their growth and provided with an "individually tailored tool" (Kiraly 49) which will help them become selfdirected learners in the professional setting upon graduation.

\subsection{The portfolio as a Self-Regulation tool}

A portfolio may be described as "a purposeful, systematic process of collecting and evaluating student products to document progress toward the attainment of learning targets" (McMillan 231). Johnson (102) remarks that the portfolio may "provide students with a framework for organizing their work and documenting their progress." Product-oriented portfolios consist of a selection of a student's best pieces of work, whereas process-oriented portfolios include all student's work, and are accompanied by a student's reflective statements (ibid.). In this way, the portfolio is "an efficient support tool for all the reflective and self-regulating tasks performed by the student" (Arumí Ribas 108).

By the very nature of the process, SI is highly marked by the oral component. Unlike translation, SI is of intangible character, which makes it hard to both reflect upon and assess. Hence, the risk of losing essential information is particularly high due to immediacy and speed at which it is performed. Students are also likely to lose focus and motivation if they are not confronted with a tangible observation of the progress being made. Seeing that 
the portfolio is a tangible product, it is hugely advantageous for SI courses, as trainees are confronted with actual evidence of their progress. However, unlike translator training (cf. Sawyer; Johnson; Way), implementing portfolios in the interpreting classroom has not yet been extensively explored (cf. Arumí Ribas; Pędzisz). The perspective advocated for in this paper is a process-oriented portfolio tailored to the individual needs of the given student.

\section{PILOT STUDY: \\ INTRODUCING THE SI PORTFOLIO INTO THE CLASSROOM}

The pilot study involved ten volunteer second-year MA students of English Studies at the John Paul II Catholic University of Lublin, whose curriculum offers one-term of initial SI training between Polish and English. The portfolio was introduced in late February and completed in early June 2019. Students presented their portfolios in loose-leaf binders or folders.

The goals of implementing the portfolio encompassed: providing students with a tangible framework for organizing their work and documenting their progress (Johnson), increasing awareness of the role of self-diagnosis and self-education (lifelong learning), supporting self-reflective practice, identifying one's strengths and weaknesses, planning activities towards a given goal, learning to reinforce the strengths and work towards solutions to the weaknesses by specifying which factors propagate efficient and inefficient interpreting performance, visualising the progress being made, increasing intrinsic motivation, focusing on process and not merely on the result.

With regard to implementing the notion of multiple voices, the source of the feedback encompassed not only the teacher but also fellow novice interpreters (peer-assessment), and the student in question (self-assessment). Trainee interpreters were actively encouraged to draw up their portfolios and work on their progress both in- and out-of-class.

\subsection{Self-Regulation elements in the Si Portfolio}

The interpreting portfolio comprised ten parts. The first part thereof were Introductory sheets, which included questions as to the emotions accompanying the student's performance, specifying what was particularly challenging, what could be improved and how, as well as what the student was happy 
about. The aim thereof was to introduce students to the narrative of self-reflection when doing very first introductory exercises (e.g. shadowing) and first attempts at SI. Hence, they were meant to encourage students to actively observe themselves and draw conclusions as to the further development.

The second part, The Wheel of Progress I, constituted the crucial element of the entire portfolio. This exercise draws on a classic coaching practice (Rogers $129 \mathrm{ff}$.). Also referred to as "the Balance Wheel," this exercise prompts the coachee to assess their satisfaction with their life as it is now, followed by comparing it with how they would like it to be, and planning strategies to achieve this goal. The wheel is separated into eight areas. The centre of the wheel represents zero satisfaction and the outer edges - total satisfaction. This exercise "encourages clients to see their lives as a whole often for the first time" (Rogers $130 \mathrm{ff}$.). Further steps include the coachee identifying the links between the scores in respective wedges, and specifying which particular area they currently intend to concentrate on (ibid.). Taken into account that the aforementioned exercise corresponds to the definition a self-assessment tool encouraging reflective thinking, and drawing on the classic version of the aforementioned exercise, a similar concept has been designed under the name "Wheel of Progress." Here, novice interpreters are expected to assess their perceived satisfaction level in eight areas they were free to choose from (grammatical correctness, phonetic accuracy, etc.) from 1 (inefficient) to 10 (highly efficient) by marking the respective levels in the wheel, based on the recorded SI performance, and discover the links between the areas. The ultimate goal was to visualise the current diagnosis of the learning situation and encourage students to identify one key area and work specifically on it so that the rest of the satisfaction level in all other areas would increase. The exercise was performed as soon as students were already able to perform their first proper SI attempts.

Having drawn up the Wheel, students set their SMART goals. ${ }^{1}$ In the meantime, as they were pondering upon possible activities they may implement on a daily basis, they filled in The Brainstorming sheet. Students were expected to name as many options as possible to achieve one major goal specified in the Wheel of Progress. This step was followed by selecting one major and two follow-up activities which students would incorporate in their daily practice. Similarly as at the prior stages, students were accompanied by the teacher's ongoing mentoring.

\footnotetext{
${ }^{1}$ SMART stands for specific, measurable, attainable, realistic, time-bound. For more detail, see e.g. Doran.
} 
As soon as students successfully planned their activities leading to their goals, they were encouraged to track their progress outside the classroom by marking each day as they accomplished their planned activities in the Progress Tracking sheets (blank monthly calendar) by adding short comments and precisely indicating how much time they spent on the given activities throughout the course outside the classroom. This part accompanied them throughout the entire term on an ongoing basis so that they would maintain their motivation and focus on working towards the goals.

While providing students with regular feedback from the teacher, selfand peer-assessment was gradually introduced. Having drawn up the aforementioned parts, students were expected to record and assess their SI performance in Self-Review sheets as they interpreted speeches both in- and outof-class. If the latter was the case, students were encouraged to interpret speeches of their choice in order to foster their autonomy. Also, students were encouraged to change their perspective, as they are expected to assess their peer's performance (Peer-Review) and by doing so, compare their own performance to the others' performance (multiple voices).

After thirteen weeks of intense training, students were asked to graphically re-assess themselves (Wheel of Progress $I I$ ) in precisely the same areas they selected previously.

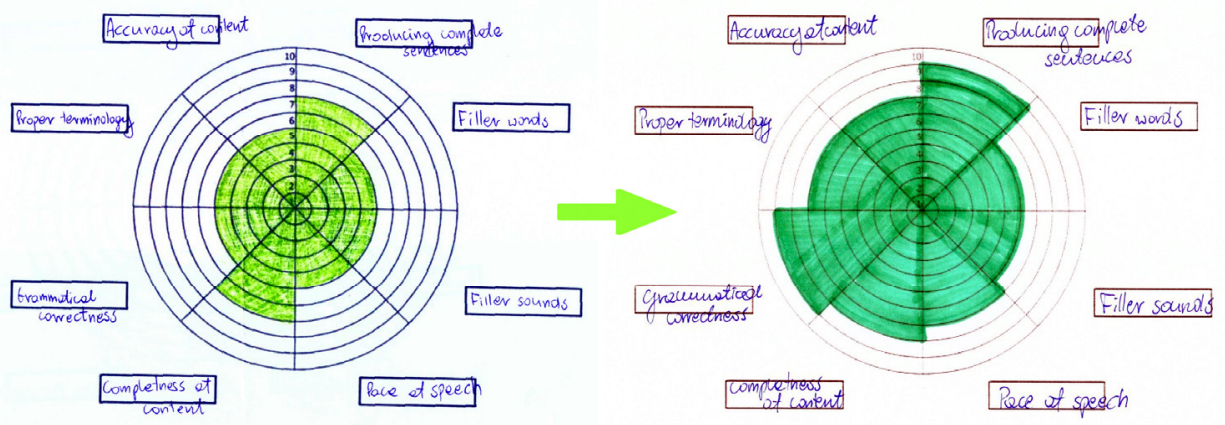

Figure 1. Exemplary progress made by a student marked in the Wheel of Progress I-II.

Students were also encouraged to reflect upon the entire process ( $M y$ Progress): to observe what skills have been improved, to indicate what they are proud of, what they should still be working on, and to design the strategic plan for the future. The implementation of self-regulation in the Portfolio is summarised in the table below. 
Table 2. Self-regulation in the SI Portfolio.

\begin{tabular}{|c|c|c|}
\hline $\begin{array}{l}\text { Self-regulation components } \\
\text { (Moser-Mercer 2008: 14) }\end{array}$ & $\begin{array}{l}\text { Self-regulated learning process } \\
\text { (Moser-Mercer 2008: 14) }\end{array}$ & $\begin{array}{l}\text { Implementation } \\
\text { in the SI Portfolio }\end{array}$ \\
\hline 1. Self-observation & 1. Analysing the task & $\begin{array}{l}\text { Introductory sheets } \\
\text { Wheel of Progress I, II } \\
\text { Self-review }\end{array}$ \\
\hline \multirow{2}{*}{ 2. Self-judgement } & $\begin{array}{l}\text { 2. Setting task-specific goals } \\
\text { strategic planning }\end{array}$ & $\begin{array}{l}\text { Brainstorming } \\
\text { Setting SMART goals }\end{array}$ \\
\hline & 3. Monitoring progress & $\begin{array}{l}\text { Progress tracking (ongoing) } \\
\text { Self-review, peer-review } \\
\text { Wheel of Progress I vs. II } \\
\text { My Progress }\end{array}$ \\
\hline \multirow[t]{2}{*}{ 3. Self-reaction } & $\begin{array}{l}\text { 4. Adjusting the strategies and ef- } \\
\text { forts based on their perception } \\
\text { of on-going progress }\end{array}$ & \multirow[t]{2}{*}{$\begin{array}{l}\text { Progress tracking (ongoing) } \\
\text { Setting SMART goals } \\
\text { My Progress }\end{array}$} \\
\hline & $\begin{array}{l}\text { 5. Using motivational strategies to } \\
\text { stay focused }\end{array}$ & \\
\hline
\end{tabular}

In view of the structure of the portfolio described earlier in this section, the table presented above is almost self-explanatory. As hinted above, the students' activities were accompanied by the teacher's mentoring on an ongoing basis - they were given an opportunity to consult doubts and plan step-by-step strategic actions aimed at the given goal by reinforcing successful and modify questionable strategies.

\subsection{The effectiveness of the Si Portfolio}

The final part of the Interpreting Portfolio included the questionnaire. In the first question, students were asked to mark answer whether they agree, disagree, or have no clear opinion about a given statement. The following questions were open-ended. The students' exemplary comments are quoted in brackets. 


\subsubsection{How would you describe the SI Portfolio?}

Nine out of ten respondents agreed that preparing the portfolio can be described as "eye-opening." One respondent had no clear opinion. All of the students unanimously agreed that the portfolio enabled them to "identify their strengths and weaknesses." Similarly, all ten students admitted that the portfolio helped them "visualise the progress made," "better understand the process of SI," and "understand that they are responsible for their achievements." Students also agreed that the portfolio enabled them to "better motivate themselves," "appreciate the progress and not merely focus on the result," and "develop their SI skills," with one respondent having no clear opinion in each instance. In the open-ended section, one student described the portfolio as "useful" and "very good for self-learning."

\subsubsection{How did the Portfolio help you develop your SI skills?}

Students emphasised that the portfolio helped them not only identify the weaknesses but also appreciate the strengths ("I've discovered my weaknesses and learnt how to improve or even eliminate them," "All that made me aware of my own weaknesses on which I had to work, but also helped me notice my strengths"), monitor the progress made ("I believe that the program was very successful because I can easily notice significant differences in between how my interpreting skills looked like at the beginning of the course and how they are now," "It helped me a lot. Now, I can definitely see the improvement"), manage stress and overcome barriers ("I am not afraid of SI anymore," "It helped me manage my stress and frustration"). Also, it helped students plan strategically ("It provided me with the concrete plan what to do step by step, which made the undertaking not overwhelming and tiresome, not laborious, but possible"), provided them with an opportunity to develop a process-oriented approach (I've discovered that regular practice is very important for constant self-improvement"), and, perhaps most importantly, the ability to perform self-assessment ("Most of all, I have discovered how to critically assess my own achievements in all sincerity").

\subsubsection{How much time did you spend working on your SI skills outside the classroom?}

Students were encouraged to undertake additional activities leading towards their goals and track their progress in the SI Portfolio. The entire course was held throughout one term, which amounts to fifteen weeks, each class 90 minutes long. As can be inferred from the table, the average length 
of declared out-of-class independent practice amounts to 616 minutes, which is an equivalent of over six additional classes, which amounts to the course being prolonged by $40 \%$ of the normal length. This result is extremely encouraging. Hence, encouraging an independent out-of-class practice is certainly an element worth implementing in the interpreter course.

Table 3. The students' declared time spent on self-regulation practice outside the classroom.

\begin{tabular}{|c|c|}
\hline Student & Time in minutes \\
\hline 1. & 250 \\
\hline 2. & 360 \\
\hline 3. & 360 \\
\hline 4. & 426 \\
\hline 5. & 580 \\
\hline 6. & 600 \\
\hline 7. & 721 \\
\hline 8. & 825 \\
\hline 9. & 960 \\
\hline 10. & 1080 \\
\hline
\end{tabular}

\subsubsection{Would you like to continue working with the SI Portfolio?}

Why (not)?

Eight students declared their willingness to continue working with the portfolio, whereas the two remaining ones were more apprehensive. In terms of positive opinions, students declared their enthusiasm because of the advantages their noticed, including motivation boosting, progress tracking and visualisation (e.g. "Yes, because I can track my progress and see what has to be improved," "Yes, because it is a motivating and convenient way of visualising and monitoring my progress especially in the long-term training"). The remaining students emphasised their plans for further self-practice ("Not sure if I want to continue with a portfolio, but for sure I want to practise more!"). Thus, even more critical voices still appreciate the value of selfregulation. As can be inferred, the feedback was overwhelmingly positive and confirmed the students' positive attitude towards working with the SI Portfolio. 


\section{CONCLUDING REMARKS}

Taking into account that self-regulatory skills are usually that of an already experienced and autonomous interpreter, the article is intended to signal the importance of promoting self-regulation as early as in the interpreting training, which should be aimed at preparing novices for the job demands outside the academia. Hence, it is of utmost import for novice interpreters to be equipped with tools that enable them to develop their self-regulatory skills, such as the SI Portfolio put forward in this paper. The corollaries borne out of the study indicate that the SI Portfolio proved to be a hugely efficient tool in the interpreting classroom and beyond. It enabled novice interpreters to raise their awareness of their own capabilities and limitations, set clear goals in terms of professional development, develop strategic actions leading to their goals, amplify successful ones and modify questionable ones, monitor the progress, maintain motivation, and ultimately prepare them to consciously direct and monitor their future professional careers.

The conclusions presented above are of a preliminary nature - the pilot study needs to be enlarged by new groups of novice interpreters. Nonetheless, the results and conclusions presented in this article will hopefully serve as pedagogical implications for SI didactics.

\section{BIBLIOGRAPHY}

Arumí Ribas, Marta. "Formative Assessment in the Interpreting Classroom: Using the Portfolio with Students Beginning Simultaneous Interpreting." Current Trends in Translation Teaching and Learning, vol. VIII, ed. Mikel Garant, University of Helsinki, Department of Modern Languages, 2010. http://www.cttl.org/2010-edition.html. Accessed 07.10.2019.

Doran, George T. "There's a S.M.A.R.T. Way to Write Management's Goals and Objectives." Management Review, vol. 70, issue 11, 1981, pp. 35-36.

González Davies, Maria. Multiple Voices in the Translation Classroom: Activities, Tasks and Project. John Benjamins, 2004.

Grow, Gerald. "Teaching Learners to Be Self-Directed.” Adult Education Quarterly, vol. 41, issue 3, 1991. pp. 125-149. doi: 10.1177/0001848191041003001.

Johnson, Julie. "Learning through Portfolios in the Translation Classroom." Beyond the Ivory Tower Rethinking Translation Pedagogy, ed. Brian James Baer and Geoffrey S. Koby, John Benjamins Publishing Company, 2003.

Kiraly, Don. A Social Constructivist Approach to Translator Education. Empowerment from Theory to Practice. St. Jerome Publishing, 2000.

Klimkowski, Konrad. Towards a Shared Curriculum in Translator and Interpreter Education. Wydawnictwo Wyższej Szkoły Filologicznej we Wrocławiu, 2015. 
"Assessment as a Communicative Activity in the Translation Classroom." inTRAlinea Special Issue: New Insights into Translator Training, ed. Paulina Pietrzak, 2019, $\mathrm{http} / / / \mathrm{www}$. intralinea.org/specials/ article/ assessment_as_a_communicative_activity_ in the translation_classroom. Accessed 07.10.2019.

McMillan, James H. Classroom Assessment: Principles and Practice for Effective Instruction. Allyn and Bacon, 1997.

Moser-Mercer, Barbara. "Skill Acquisition in Interpreting. A Human Performance Perspective." The Interpreter and Translator Trainer, vol. 2, no. 1, 2008, pp. 1-28.

Pędzisz, Joanna. "Kształcenie thumacza symultanicznego a trening rozwoju osobistego. O portfolio thumaczeniowym jako narzędziu wspierającym samopoznanie." Applied Linguistics Papers, vol. 26, no. 2, 2019, pp. 91-102. doi: 10.32612/uw.25449354.2019.2.

Pietrzak, Paulina. "The Effects of Students' Self-regulation on Translation Quality." Babel: International Journal of Translation, vol. 64, no. 5/6, 2018, pp. 819-839. doi: 10.1075/babel. 00064.pie.

Rogers, Jenny. Coaching Skills A Handbook. Open UP, 2008.

Sawyer, David. Fundamental Aspects of Interpreter Education: Curriculum and Assessment. John Benjamins Publishing Company, 2004.

Schraw, Gregory, and Rayne Sperling Dennison. "Assessing metacognitive awareness." Contemporary Educational Psychology, vol. 19, issue 4, 1994, pp. 460-475. doi: 10.1006/ ceps.1994.1033.

Way, Catherine. "Systematic Assessment of Translator Competence: In Search of Achilles' Heel." Translator and Interpreter Training: Issues, Methods and Debates, ed. John Kearns, Continuum, 2008, pp. 88-103.

\section{PORTFOLIO JAKO NARZECZIE SAMOREGULACJI W KSZTAŁCENIU TŁUMACZY KONFERENCYJNYCH: WSTĘPNE WNIOSKI Z BADANIA PILOTAŻOWEGO}

$$
\text { Streszczenie }
$$

Z uwagi na to, że od profesjonalnych tłumaczy konferencyjnych oczekuje się autonomicznego rozwoju, zadaniem dydaktyków przekładu powinno być przygotowywanie początkujących tłumaczy do rozwoju zawodowego po ukończeniu edukacji formalnej. Jedną z najtrafniejszych koncepcji w tym kontekście jest pojęcie samoregulacji, opisane przez Barbarę Moser-Mercer. Wdrożenie elementów samoregulacji, tj. refleksji nad procesem thumaczenia oraz poczynionych postępów, praca nad jakością przekładu oraz rozwijanie praktyk profesjonalnego thumacza konferencyjnego może być ułatwione przez wprowadzenie „indywidualnie dopasowanego narzędzia” (Kiraly 49), umożliwiającego rozwój zarówno w edukacji uniwersyteckiej, jak i po ukończeniu studiów. Niniejszy artykuł przedstawia koncepcję portfolio jako narzędzia wspierającego samoregulację u początkujących tłumaczy konferencyjnych, które umożliwia im dokumentowanie i ocenianie poczynionych postępów, rozwijanie skutecznych strategii umożliwiających dążenie do wyznaczonych celów oraz skłania do refleksji nad procesem przekładu. Otrzymane wyniki oraz pozytywne reakcje zwrotne od studentów biorących udział w badaniu pilotażowym wskazują na wysoką efektywność portfolio w zakresie rozwoju umiejętności samoregulacyjnych u adeptów przekładu konferencyjnego.

Słowa kluczowe: thumaczenie symultaniczne; samoregulacja; autorefleksja; portfolio. 


\section{THE INTERPRETING PORTFOLIO \\ AS A SELF-REGULATION TOOL IN INTERPRETER TRAINING: PRELIMINARY FINDINGS FROM A PILOT STUDY}

\section{Su m m ary}

Given that professional interpreters are expected to work in a highly autonomous mode, it is crucial for T\&I (Translation and Interpreting) didactics to prepare novice interpreters for the life upon graduation. One of the most pertinent approaches in this context is self-regulation put forward by Barbara Moser-Mercer, whereby students ultimately become self-directed learners. Implementing self-regulatory elements in the SI (simultaneous interpreting) classroom entails introducing strategies such as self-reflection and self-monitoring. Inspiring reflection upon the process and one's own progress, working towards higher quality standards, and developing the practices of a professional interpreter may be facilitated by providing students with an "individually tailored tool" (Kiraly 49) which enables further development both in class and upon graduation. This article puts forward the SI Portfolio as a self-regulatory tool for novice interpreters in which they can reflect upon and document their progress, evaluate themselves, and develop effective strategies leading to their goals. The results obtained and the positive feedback from the students who participated in the pilot study indicate that implementing the SI Portfolio may be highly efficient with regard to developing selfregulatory skills in novice interpreters.

Key words: simultaneous interpreting; self-regulation; self-reflection; portfolio. 